\title{
EDUCATION MANAGEMENT OF POLICY REFORM OF \\ EXTRAORDINARY SCHOOL KNOWN AS (SLB) IN CENTRAL JAVA PROVINCE
}

\author{
Diyah Etana* \\ Endang Larasati \\ Yuwanto \\ Sundarso \\ *Correspondent Author: DiponegoroUniversity, Faculty of Social And Political Sciences, prodidap@gmail.com
}

\begin{tabular}{|c|c|}
\hline Article history: & A b s t $\mathbf{r}$ a $\mathbf{c} \mathbf{t}$ \\
\hline $\begin{array}{l}\text { Accepted } 29 \text { August } 2019 \\
\text { Available online } 31 \text { December } 2019\end{array}$ & Every citizen has the same rights to obtain the education, including for children with disabilities. \\
\hline & However, from the current researchers there are several problems faced with the implementation of \\
\hline Keywords: & Extraordinary School (SLB) education in Central Java Province, which is the limitation of human \\
\hline Policy Reformation & resources policy, budget and infrastructure facilities. This research aims to observe and conduct \\
\hline Disability & 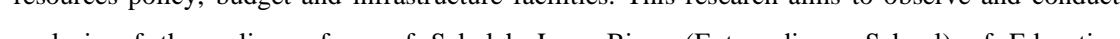 \\
\hline Standard Operational Procedure & analysis of the policy reform of Sekolah Luar Biasa (Extraordinary School) of Education \\
\hline Education Management & management in Central Java Province and supporting factors and inhibitors of SLB education \\
\hline Extraordinary School & management policy conducted by the government of Central Java Province. The research method \\
\hline & used by researchers is qualitative, with data collection using triangulation techniques. The results \\
\hline & showed that the policy reform of SLB Education management in Central Java Province in the field \\
\hline & of apparatus resources still need to be addressed because still many who have not been literate with \\
\hline & technology. However, it does not affect them in the service given to the community. These \\
\hline & recommendations given improving the quality and quantity are human resources apparatus through \\
\hline & the technology and training. The addition of personnel, development of infrastructure adapted to \\
\hline & disabled, master data collection and budget adjustments. Preparation of Standard Operational \\
\hline & Procedure (SOP) sustained to the LAW No 8 in 2016 about the disabled. The creation of governor \\
\hline & that is specifically governs the disability. \\
\hline
\end{tabular}

\section{Introduction}

Every country needs a policy to direct actions so that the desired objectives achieved. This is in line with the opinion expressed by (Anggraeni, Zauhar, \& Siswidiyanto, 2011) in a book entitled: Public Policy Evaluation. "Policy is an act that leads to a goal proposed by a person, group or Government in a particular environment in connection with certain obstacles while looking for opportunities to achieve goals or Desired Goal. The policy contains an element of action to achieve the goal. Generally, the goal achieved by a person, group or government. The policies certainly face various obstacles or problems but have to look for opportunities to realize the desired objectives.
The problem of education faced by the Indonesian nation is the low quality of education at every level and unit of education. The Report comes from the United Nations Development Program (UNDP) in 2016 about the Human Development Index (HDI). The composition of the achievement stage in education, reported that in 2015 Indonesia was at the rate of 113 from 188 countries, and still low Compared to some of the countries in Asia Pacific such as Singapore, Hong Kong, Japan, Malaysia, Thailand and China, which seen in Figure 1 below. 
Figure 1. Human Development Index In Asia-Pacific Countries

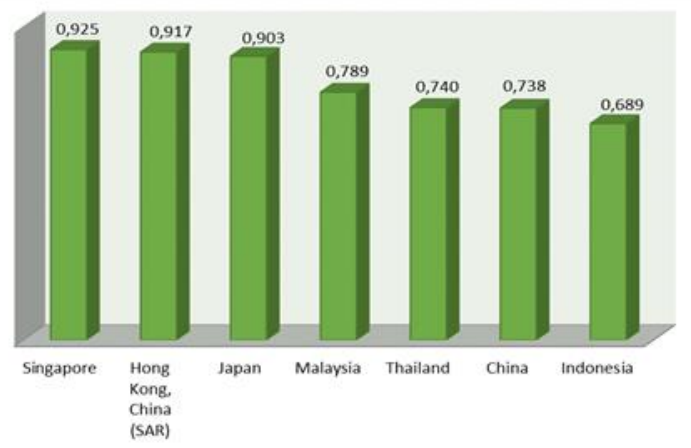

Source: Human Development Index, 2016

Based on the figure above, known that HDI for Indonesia in 2015 is the lowest compared to five other Asia Pacific Countries. Indonesia ranks 113 with a score of 0.689 . The highest HDI obtained by Singapore with a score of 0.925 . It ranks five out of 188 countries. Low HDI shows the low competitiveness of the nation in global trade.

National education has a very important role for citizens. National education aims to educate the life of the nation; therefore every citizen has the right to get an education. As stated in (Kemendikbud, 2013) stated that every citizen has the same opportunity to obtain an education. This indicates that the disabled child may also have the same opportunity as other children in education.

The World Health Organization (WHO) in 2010 revealed that $10 \%$ of the world's population is a disability, approximately 600 million people. While the data Ministry of Health Indonesia in 2010 recorded, the number of special disabilities in Indonesia reaches 6.7 million consisting of blind, dumb, deaf, disablement and other types of defects. In 2012, WHO wrote that there were 285 million people experiencing visual impairment around the world, 39 million people had blindness and 246 million of people suffered from low vision. A number of $90 \%$ case blindness (low vision) occurs in developing countries.

Exclusion, marginalization, and discrimination against people with disabilities are still a tough challenge for their opportunities to live on par with other communities. Based on the results of the data from the Ministry of Social Affairs of Indonesia Republic in 2009 , about $67.33 \%$ of adult disabilities have no skills and employment. For those who have a job, the main skill types of disability are massage, crafting, farmer, labor, and services.

According to (Lusli et al., 2015), the change of disability data in a survey of Statistical Center (BPS) from health indicators to become indicators of social welfare since 1998 raises difficulties to Determine the actual magnitude of a disabled resident, especially since the operational definitions used change frequently. The results of unbiased surveys, such as RISKESDAS 2007 and the World Bank trials in 2007, are estimated to be no less than $2-3 \%$ of the Indonesian population with disabilities that interfere with the function and daily social activities.

Figure 2. Number of Disability in Indonesia

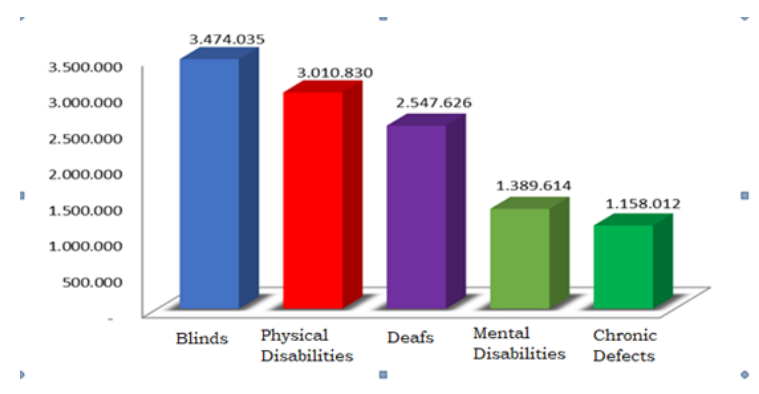

Source: Social Ministry of Indonesian Republic, 2011

Social Ministry of Indonesia Republic as of December 2010 mentions the number of people with a disability in Indonesia $11,580,117$, consisting of a blind $3.474,035$ people, disability is $3,010,830$ people, deaf is as many as $2,547,626$ people, mentally disabled is $1,389,614$ people and chronic disability is as many as $1,158,012$ people. Based on the Social Ministry data, this shows that the blind have the largest amount compared to other types of others.

Data reported from the provincial government of Central Java in this case the provincial education office of Central Java, that there are about 14,544 students of Extraordinary School (SLB). By details for Kindergarten Extraordinary School (TKLB) of 574 students, Elementary Extraordinary School (SDLB) as many as 9,785 students, Junior School of Extraordinary School (SMPLB) as many as 2,697 students, Senior High School of Extraordinary School (SMALB/SMKLB) as many as 1,468 students, and Vocational School as many as 20 students. Where more details seen in figure 3 below.

Figure 3. Number of Extraordinary School (SLB) Students in Central Java Province

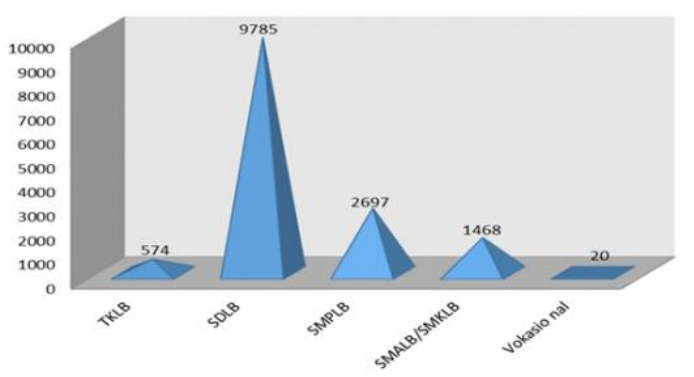

Source: Educational Institution of Central Java, 2016 
Regardless of the large or small number, given that the inherent number of the figure is the soul, then any number is a number that requires the attention and concern of all elements of the nation and inherent to that number of human rights demanded to be respected, fulfilled and protected. Another problem that arose after the education authority of Extraordinary School (SLB) taken over by the Provincial Government of Central Java from the district/city government besides Human Resources (HM), and infrastructure is the field of budget associated with a diminished Extraordinary School (SLB) teacher's welfare problem, especially teachers in Private Extraordinary School (SLB).

Where many honorary teacher incentives in private Extraordinary School (SLB) after the transition of authority was carried out from the district/city which was taken over by the Provincial Government of Central Java, it has an impact on the loss of their incentives. Such practices are not reformist, when the management authority of Extraordinary School (SLB) is pulling back to the level of the Provincial Government of Central Java. Because in practice cannot be in accordance with what is expected by the honorary teachers in private Extraordinary School (SLB) that are widely scattered throughout the province of Central Java today. Where it seen in figure 4 below.

Figure 4. The Amount of State and Private Extraordinary School (SLB) in Central Java Province

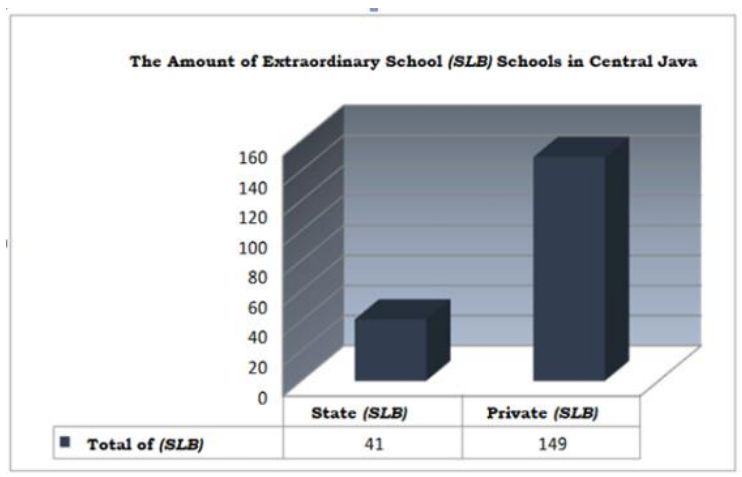

Source: Educational Institution of Central Java Province, 2016

Based on Figure 4 above, it can be noted that the number of Extraordinary School (SLB) of state in the Central Java Province is currently only 41 Schools, while for Extraordinary School (SLB) which is managed by the private sector more compared with the current state of Extraordinary School (SLB) with number of schools as much as 149 . While teacher incentives lost due to the management of Extraordinary School (SLB) in the back to the level of the Provincial Government of Central Java reached thousands. As shown in Figure 5 below.
Figure 5. Number of SLB's Teachers of Civil servants and NonCivil servants of Central Java province

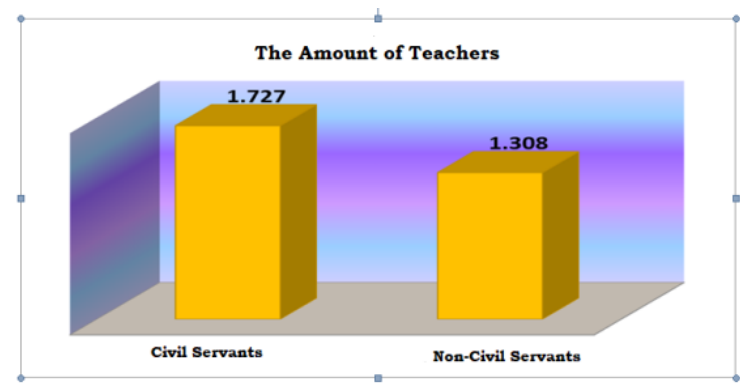

Source: Educational Institution of Central Java Province, 2016

Based on Figure 5 above, it can observe that the number of teachers from civil servants in Central Java Province is currently 1,727, while Non-Civil Servant teachers who are threatened incentive disappear because they caused by the management authority of the SLB in pulling back to Central Java provincial Government amounted to 1,308. SLB's withdrawal policy to the provincial government began in 2014, through (Pemerintah Republik Indonesia, 2014) on local government and (Kementerian Pendidikan Nasional, 2010) on previous management and implementation of education, all assets, teachers and Management of Extraordinary School (SLB) is the provincial authority. In addition, this withdrawal is in order for the provincial government of Central Java to responsible as a special education provider. Ensure if the provincial government of Central Java manages and develops this Extraordinary School (SLB) in Central Java Province and conducts more comprehensive coaching for special education in Central Java. However, nothing has done in accordance with the planned, so there are still a lot of problems that arise.

According to the data above showed that the management of Extraordinary School (SLB) in Central Java Province needs reconsidered. Particularly, for teacher's resources taking placed in separated Extraordinary School (SLB) and its public service, seen from still the least number of Extraordinary School (SLB) standing in the region of Central Java provincial Government today. And this is the interest of researchers to conduct a study related to policy reform that focus on the human resources apparatus and services to people who have children with disability condition. As stated in the Grand Design of the current bureaucracy reform, which examined in the bureaucracy reform, it includes its human resources and its public service so that it can affect the public in general. This research aims to conduct a reform analysis of the education management policy of SLB in Central Java province, which seen from the human resource factor of apparatus, and public service. 


\section{Research Method}

This research uses qualitative data analysis and the technique analysis is applying quantitative data. Where this method is a method of research that is not the same as the experimental method, this method of research used to examine the condition of natural objects and Researchers have a duty and function as a key instrument in observing a key problem that revealed in a research object that it would implement. By testing the validity and validity of data are using triangulation techniques.

\section{Literature Review}

\subsection{Public Policy}

The scope of public policy studies is broad because it has various fields and sectors such as economics, politics, social, culture, law, and so on. Besides judging from the hierarchical public policy can be national, regional and local such as legislation, government regulation, presidential regulation, ministerial regulation, regulation of the local government/province, the decision of the Governor, Regency/City, and the decree of the Regent/Mayor.

In terms of public policy understanding, it turns out a lot, depending on which point we interpret. (Profwork.org, 2014) provided a definition of public policy as the authoritative alocation of values for the whole society or as a forcibly allocation of values to all members of the community. (Kaplan \& Lynch, 2001) also interpreted public policy as a capacitance program of goal, value, and practice or a program of achievement of objectives, values in directed practices.

The public policy according to (Dye, 2016) defined as "Whatever governments choose to do or not to do". Public policy is what the government chose to do or did not do something. This understanding indicates that the government has the authority to make choices about which policies performed or not, depending on the issues arising or the achievement that is intended addressed by the policy. Meanwhile, the policy sense expressed by (Bohara, Mitchell, \& Mittendorff, 2004) defined public policy as a series of actions that a person, group or Government proposes in a particular environment, with existing threats and opportunities, where the proposed policy intended to Potential and overcome obstacles in order to achieve certain objectives.

It differents from the opinion of the experts above (Dye, 2016) in (Joko, 2016) suggested that in the policy system there are three elements cosists of "(a) Stakeholders policy; (b) Policymakers (policy contents); and (c) policy environment ". Based on the theory, you can be aware that a policy creates by the Government to achieve certain objectives in which there are perpetrators involved in addressing the problems arising from the environment. As (Anderson, 1990) elements stated in the public policy, among other things includes the following as follows:

1. Policies always have a purpose or are oriented towards a particular purpose.

2. The policy contains actions or patterns of action of government officials.

3. Policy is what the government is actually doing and not what it intends to do.

4. Public policy is positive (which is the Government's action on a particular matter) and is negative (the decision of government officials not able to do anything).

5. Public policy (positive) always based on certain rules of law that are pushy (authoritative).

Public policy created as is intended to address issues that arise in the community, formulating problems is one of the phases in policymaking, so formulating problems is fundamental to policy making. (Dunn, 2003) described some important features of policy issues, classified as follows:

1. Interdependence is among policy issues. Policy issues within a field sometimes affect policy in other areas. (Meyer \& Dunn, 2006) suggested that in reality policy issues are not a standalone unity; they are part of the whole system of problems that best described as Meses, that is, an external condition system that generates dissatisfaction among different segments.

2. The subjectivity is among policy issue. External conditions that pose a problem defined, classified, described and selectively evaluated. While it consists of a presumption that the problem is objective, the same data on a problem interpreted differently.

3. Artificial nature is among the problem. Policy issues are only possible when humans make judgments about the desire to change some of the problem situations. Policy issues constitute a result/product of human subjective judgment; that policy problem also accepted as legitimate definitions of objective social conditions; and changed socially.

4. Dynamics is among policy issues. They consist of many solutions to a problem, as many definitions to the problem. Problems and solutions are in constant changes; and hence the problem not constantly solved. The solution to the problem can be obsolete even though the problem itself is not obsolete.

Public policy on addressing a problem also contains various concepts. (Anderson, 2003; Sugandi, 2017) defined public policy as "a response from the political system to demands/claim and support that flows from its environment". In policy making to address community issues, the policy contains values that aligned 
with the prevailing values in the community that will directly or indirectly impacted by the policy. As (Eulau \& Easton, 2006) presented in (Kawer, Baiquni, Keban, \& Subarsono, 2018) said that "When the government makes public policy, it is also the government to allocate values to the community, because each policy contains a set of values in it" . In line with this, (Lasswell \& Kaplan, 2018) in (Kawer et al., 2018), argued, "public policy should contain the goals, values, and social practices that exist in the community". Public policy should not contradict the values and social practices that exist in the community, in order not to occur rejection or resistance when implemented..

\subsection{Policy Reform Concepts}

The basic conception of reform is to create changes, improvements, arrangements and settings comprehensively and systematically on many matters, especially as it relates to leadership, as well as to State, Organize and Government.

Reform defined as the process of change from the old condition to the desired new condition (Said, Abdullah, Uli, \& Mohamed, 2014). Whereas according to the opinion of (Novianto, Kurniawan, \& Wibawa, 2017) stated that a movement to change the shape and behavior of a setting, because the order is no longer preferred or not according to the needs of the times-good because it is inefficient, not clean, not democratic, etc. According to (Hidayat, 2017) stated that reform is a corrective or changing form.

(Anderson, 2003) in (Nugroho, 2017) defined the policy as "A relative stable, purposive course of action followed by an actor or set of actor in dealing with A problem or matter of concern." Policy is the direction of action that has the intent set by an actor or a number of actors in addressing a problem or issue.

According to the explanation above it noted that the understanding of public policy reform is to change the behavior or action better to be more effective and efficient than the actors in addressing a problem that are occurs in the society of today.

\subsection{Bureaucracy Reform Concepts}

Relating to the Government's efforts in fixing the bureaucracy, which eventually referred to as bureaucratic reform? Thus, there are various definitions of bureaucratic reform, with varying understanding of bureaucracy reform.

According to (Sedarmayanti, 2011) stated that bureaucracy reform was the government's effort to improve performance through various ways with the aim of effectiveness, efficiency, and accountability. Where the bureaucracy reform includes several changes namely (a) Changing in way of thinking; (b) Changing of ruler into Civil Servant; (c) Putting the role of authority; (d) Not think the production result but the final result; (e) Changing in performance management.

The explanation above shows that to reform bureaucracy there are some things changed from the bureaucracy itself. After seeing the various explanations of bureaucracy reform above, bureaucracy reform is part of administrative reform, could said in relation to actions or measures undertaken in the reform the administration of one of its objectives is to reform bureaucracy.

In the Grand Design Bureaucracy Reform in the period of 20102025 It had determined that the objectives achieved in bureaucratic reform are to create professional government bureaucracy with adaptive, integrity, high performance characteristics. It also shold be clean and free of Corruptio, Collusion and Nepotism, being able to serve the public, neutral, prosperous, dedicated, and uphold the basic values and ethics code of the State Apparatus. There are 8 (eight) areas of change that become the goal of bureaucracy reform covering all aspects of government management, as stated in the table below:

Table 1: These 8 Areas of Bureaucracy Reform Changing

\begin{tabular}{|c|c|}
\hline Areas & Results Expected \\
\hline Organization & $\begin{array}{l}\text { Proper organizational function and } \\
\text { precise size (right sizing) }\end{array}$ \\
\hline Execution & $\begin{array}{l}\text { Clear, effective and efficient, } \\
\text { measured and in accordance with } \\
\text { good governance principles, } \\
\text { systems processes and working } \\
\text { procedures }\end{array}$ \\
\hline Laws and Regulations & $\begin{array}{l}\text { Regulation that is more orderly, not } \\
\text { overlapping and conducive }\end{array}$ \\
\hline $\begin{array}{l}\text { Human Resources } \\
\text { Apparatus }\end{array}$ & $\begin{array}{l}\text { Human Resource apparatus is } \\
\text { integrity, neutral, competent, } \\
\text { capable, professional, high } \\
\text { performance and prosperous. }\end{array}$ \\
\hline Supervision & $\begin{array}{l}\text { Increased governance of clean and } \\
\text { free of Corruption, Collusion and } \\
\text { Nepotism }\end{array}$ \\
\hline Accountability & \begin{tabular}{llr} 
Increasing & \multicolumn{2}{c}{ capacity and } \\
accountability for bureaucratic \\
performance
\end{tabular} \\
\hline Public Service & $\begin{array}{l}\text { Excellent service according to the } \\
\text { needs and expectations of society }\end{array}$ \\
\hline $\begin{array}{lrr}\text { Mind } & \text { Set } & \text { And } \\
\text { Cultural } & & \text { Work }\end{array}$ & $\begin{array}{l}\text { Bureaucracy with high integrity and } \\
\text { performance }\end{array}$ \\
\hline
\end{tabular}




\begin{tabular}{|l|l|}
\hline $\begin{array}{l}\text { (Culture Set) } \\
\text { Apparatus }\end{array}$ & \\
\hline
\end{tabular}

Bases on these definitions, in the interest of the authors ' research is to take a generalization of bureaucratic reform concept (administrative) that is a change efforts made by the Government in the governance system to create or make things better than the previous state by involving bureaucracy as the target of change so that bureaucracy becomes more qualified. In addition, using the eight areas of change in the Grand Design bureaucracy reform 2010-2025 became a tool to parse the current research problems. Because of the limitation of researchers then in this research will be selected two areas of change such as Human Resource apparatus and public services. The researchers choose these two areas as a matter of the problem in implementing the education management of Extraordinary School (SLB) in Central Java Province. The reason why researchers in using the Grand Design bureaucracy reform 2010-2025 is more applicative than the other theory, and is one of the mandatory government programs that should be implemented by any agency or institution Government in the entire territory of Indonesia.

\section{Result and Discussion}

The results of research that has been done in the field, for reform study of the policy of education Management of Extraordinary School (SLB) in Central Java Province has been known that it turns out the policy by the current government not maximized or optimal. This can be seen from the data obtained from the relevant instituion/agencies through the results of interviews that have been done with some informant both from the government and from the community. The head of the Education and Culture Office, the director of the Ministry of Religious Affairs, the scholarship of the Ministry of Agriculture, Educators and special education (SLB's teacher) currently represent as the informant of the Central Java provincial government. While the informant of the community in this research represented by parents who attended the Extraordinary School (SLB).

Several problems are widely alluded to by the informant of policy reform studies that have been widely complained of by some informant are both human and non-people. Moreover, some facilities of space infrastructure classes that still require improvement to be comfortable to use as a place to learn and teach while in the classroom.

Researchers in obtaining an overview of the policy reform of the education Management of Extraordinary School (SLB) in Central Java province used some of the principles contained in the Grand Design bureaucracy reform 2010-2025 to parse Current research problems. In addition, because of the limitations owned by the researchers, then in this research will be selected two areas of change such as Human Resources apparatus that is seen using the theory presented by (Notoatmojo, 2010) and public services viewed by Using the Theory of (Kasmir, 2009).

The member states transfer sovereignty always and more, by attributing them the power of creating legally dependent norms, as well as the power to adopt mutual politics, that have always been reserved from the sovereign decisions of member states. Until now we have mutual monetary, agricultural politics etc.

\section{Policy reform of Education Management of Extraordinary School (SLB) in Central Java Province}

The current policy reform conducted by the provincial government of Central Java in conducting the management of Extraordinary School (SLB) education for pupils or students with special needs can be known results. Results obtained after a thorough research with the stakeholders and the society results in the reform of the policy has not succeeded optimally. It is very conscious of some results interviews with informers that were successfully encountered by researchers at the field. Some of the informant are the Head Of Education and Culture Office, Head of Field of construction as well as Special Education, the study of student affairs, educator and education special teachers, and SLB's teacher.

The intention of bureaucracy reform, namely as a change effort to improve the bureaucracy quality. Every change to be made always focuses on the bureaucracy as a change target, this is done to solve the problems that exist in the community. Given that the bureaucracy is always in contact with the community therefore the bureaucracy is demanded to maximize its task and function as a servant in serving the community. To achieve this aim, the government as a competent authority to make renewal and fundamental changes to the system of governance.

\section{Human Resources Apparatus}

The Area of change is included in the Grand Design bureaucracy reform 2010-2025, namely human resources apparatus. Which in the weaver human resources apparatus according to (Amran, 2009) seen in two factors that can affect the human resources apparatus in the Department of Education and Culture of Central Java, internal and external factors? Researchers observe about mission and organizational objectives, achievement strategy and types of technology used use this internal factor. While in the external, factors used by researchers to observe about the 
government's wisdom, social culture, and the development of science and technology.

The results of research conducted by researchers found based on interviews and data obtained that the education management of Extraordinary School (SLB) in Central Java province. It related to human resources apparatus has not been done optimally because the vision of a mission that has not yet contained or alluded to the disability, uncertified teachers of Extraordinary School (SLB). As well as several teachers of Extraordinary School (SLB) or education personnel specialized in Extraordinary School (SLB) who have not been able to use the computer applications skillfully and well when completing the work that they are responsible for.

Based on the results of the interview explanation above, it is known that at present, the government has not succeeded the policy reform of the education Management of Extraordinary School (SLB) in Central Java province from Human Resluces factor apparatus. It is necessary to make improvements so that the quality and effectiveness of Extraordinary School (SLB) teachers can be fulfilled. For people with disabilities can face a better future in their lives later. Who has gained the knowledge and skills of their current teachers?

The Human Resource condition above is very suitable with the data in the provincial education and culture Office of Central Java. Teachers who have become civil servants currently in Central Java Province have 1,727 teachers. The following classes are seen from graph 1 below. Gar's people with disabilities can face a better future in their lives. Who has gained the knowledge and skills of their current teachers?

Graphic 1. Number of Civil Servants of Extraordinary School (SLB) Classifying In Central Java province

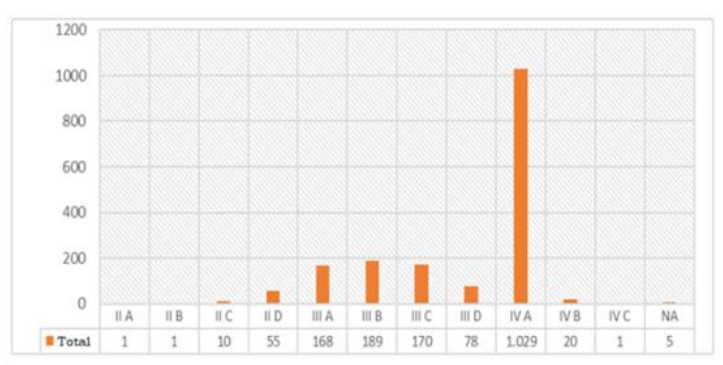

Source: Central Java Provincial Education Office, 2018

From Graph 1 above, it noted that the Extraordinary School (SLB) teachers in the current region of Central Java province are the most in-group IV A with 1,029 people. Then the second most teacher group had shown in-group III B with the number of teachers as much as 189 people. In addition, the number of teachers at least from the graph above knew, namely
Extraordinary School (SLB) Teacher with group II A, II B and IV. Each of them is only one person. Therefore, the government of Central Java province is required to add or make improvements in quality and quantity to teachers who still lack their capacity to teach students or SLB student in Central Java province. Whereas if it viewed based on the type of experience it seen in Graph 2 below.

Graphic 2. The Number of Civil Servants of Extraordinary School (SLB)'s Teachers by Gender in Central Java Province

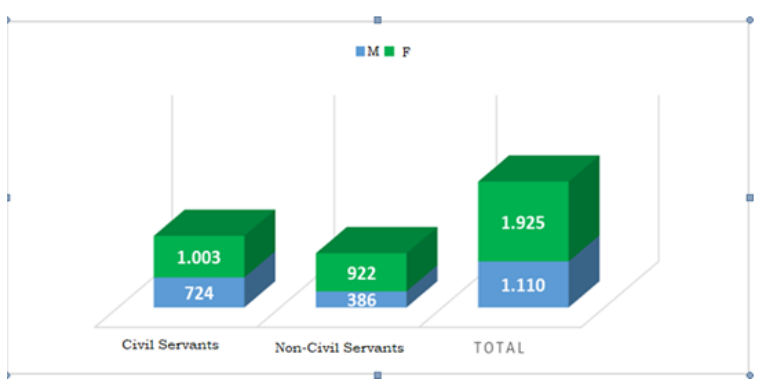

Sources: Educational Institution of Central Java Province, 2018

Based on Graph 2 above can be noted that at this time Extraordinary School (SLB) teachers located in Central Java Province in the domination of women where the total amount is 1,925 overall, with the details of the status of Civil Servants as many as 1003 teachers, and Non Civil Servants as many as 922 Extraordinary School (SLB) teachers. After that, the gender of men with a total 1,110 Extraordinary School (SLB) teachers, with the status of Civil Servants as many as 724 people and Non Civil Servants currently number as many as 386 people. Based on the results of interviews, data and facts in the field can be noted that the number of Extraordinary School (SLB) teachers in Central Java Province still needs to be added, as well as the addition of qualified teachers in educating children at the time of children with disabilities Lessons given in the classroom.

According to (Van Rensburg, Basson, \& Carrim, 2011) stated that the factors affecting human resources are two, first internal factors: mission and organizational objectives, goal achievement strategy, type of technology used and external factors: government policy, social culture, and the development of science and technology. The Human Resources factor of this apparatus used by researchers to determine the extent of the education and culture Department of Central Java in conducting the management of Extraordinary School (SLB) based on internal and external factors that have been carried out.

The results of a reform study of the education management policy of Extraordinary School (SLB) in Central Java Province that has been conducted by researchers at the time in the field can be known that currently that the Human Resource factor apparatus 
to conduct management of Extraordinary School (SLB) still need improvement by improved quality and quantity in the field. This is due to the absence of policy regulations such as the struggle or Regional Regulations, which specifically regulates education for those with disabilities. In addition, several classes of teachers who are still not skilled or not able to operate the computer to support the teaching activities of students at the time they are in front of the class. So according to them given the Training or Technologycal Guidance in order to support the education of SLB and develop the interests and talents owned by the students in Extraordinary School (SLB).

The absence of conformity between the theory conveyed by (Van Rensburg et al., 2011) the practice at the time in the field makes the management policy Program of in Extraordinary School (SLB) conducted by the Provincial Education and Cultural Office of Central Java there are still many face of the problem. So according to the informant necessary improvement efforts of the Central Java provincial government so that Extraordinary School (SLB) in Central Java province is better than when it managed by the Regency/City government. Especially it focuses on science and skills are from teachers at Extraordinary School (SLB) School. In addition, the numbers of teachers who still slightly compared to schoolteachers for other education levels also become an obstacle in fulfilling the ratio of teachers to students. Teacher improvement in quality and quantity then it can make children with disabilities can compete with other children in the middle of society today.

\section{Public Service}

The Area of change included in the Grand Design bureaucracy reform the next second 2010-2025 in this study was public service. Which in this weaver will be seen in some of the symptoms or indicators, namely the ability of officers in performing the service quickly and precisely, able to communicate well, able to maintain the secret well, have knowledge and ability, trying to understand the community necessities, and able to give confidence to the community.

Based on the results of the interview explanation that conducted by the researchers at the time of the field, it is known that the policy reform of the education Management of Extraordinary School (SLB) in Central Java Province relates to public service factor is can walk according to the society expectations. It based on the answer of the informant who said that the service provided by the Central Java Provincial education and culture office in handling the problem is responsive. They are officers quickly and precisely in providing, the clarity of information needed by both of the teachers and the community who reported related to the problem of Extraordinary School (SLB) in Central Java Province.
Therefore, in the end it can increase the trust of people who currently have children with special needs to be able to follow the education of Extraordinary School (SLB) with high enthusiasm.

The characteristics of good service according to (Jansi, Kasmir Raja, \& Sandhia, 2018) formulated as follows: 1. Responsible to each customer/visitor from the beginning to completion. 2 . being able to serve quickly and precisely 3 . Being Able to communicate 4. Being Able to provide assurance of confidentiality of each transaction 5. Have a good knowledge and ability 6. Strive to understand the needs of customers/visitors. 7. Giving confidence is to customers/visitors. Understanding the quality of services or services centered on the fulfillment of needs and desires of the community and its delivery provisions to offset the expectations that wanted by the society today. This public service factor used by researchers to determine the extent to which the Central Java provincial education and Culture department in conducting the management of Extraordinary School (SLB) is able to provide good service to the community in the field of extraordinary education for children with disabilities.

The research results conducted by researchers can be found based on the results of the description of interviews and data obtained that the management of Extraordinary School (SLB) education in Central Java Province related to the service provided to the community is already running according to what is expected. The implementor officers who come from the provincial education and cultural Office of Central Java and teachers who teach in Extraordinary School (SLB) are already able to provide good service to the community. Therefore, in the implementation it is no problem in conducting the management of Extraordinary School (SLB), after all the extraordinary education affairs taken by the provincial government of Central Java.

The alignment between theory and practice, so that the management of Extraordinary School (SLB) conducted by the Department of Education and Culture of the Central Java Province in conducting services today has been able to satisfy the various parties to the teacher, Principal as well as Community. It based on the ability of officers in performing services quickly and appropriately, able to communicate well with the principal, teachers of Extraordinary School (SLB) and society, transparent in providing data related to SLB, have knowledge and Skills about good management of Extraordinary School (SLB) is what it does. They are trying to understand the needs of the community, and able to give confidence to the community to send their children who have special need to learn to the Extraordinary School (SLB). Having good public service even though the Human Resource is still very limited to Central Java Province showed his achievements in the Olympics for students with 
disabilities who are held in Jogjakarta in the past time by bearing or Won as General champion.

Figure 6. Extraordinary School (SLB) Students of Central Java who Become Champions In Competition Events O2SN in all Indonesia

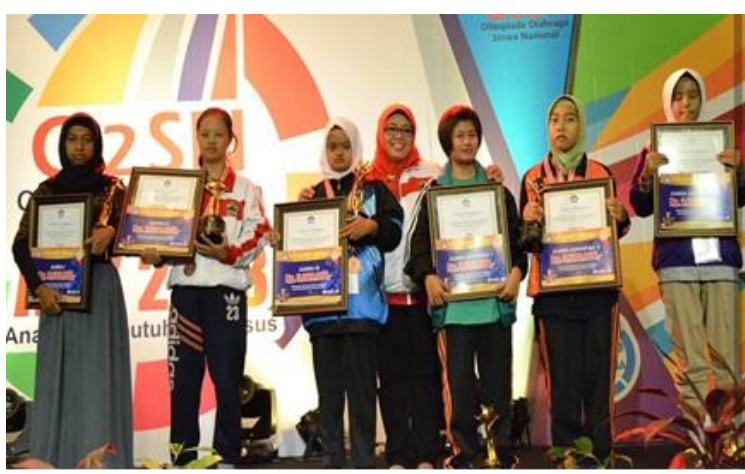

Source: Researcher Document, 2018

\section{Conclusion and Suggestions}

Research reform Study of the policy of education Management of Extraordinary School (SLB) in Central Java Province that has done by researchers previously concluded as follows:

The policy Management of Extraordinary School (SLB) education in Central Java Province as whole results in the framework of reform in the field of apparatus has not carried out well. Because up to the extent of the resource apparatus that became a phenomenon in this research, after the study in the field is, still many who have not digital literacy is to operationalize computer and props when the teacher teaches Students in front of the class.

Especially for human resources apparatus, that is middle age. However, based on the results of the study in the field they continue to do public service well, fast and responsive to the principal and SLB's teachers of whom found many problems when they learn to teach in Extraordinary School (SLB) school the that they handle today. Therefore, to improve apparatus resources especially for Extraordinary School (SLB) teachers, need to do some training to improve their quality. Therefore, those Extraordinary School (SLB) teachers can give a good understanding to their students, when teaching them in the classroom while learning to teach in the school.

Improvement efforts that need implemented on various conditions evaluation of the education management policy of Extraordinary School (SLB) are as follows:
1. Improving the quality and quantity of Human Resource apparatus through technology and training

2. The addition of current Extraordinary School (SLB) teachers is still very little, compared to the general level of education.

3. The construction of facilities that can adapted to the disability.

4. Re-collection of teachers is both of state and of private Extraordinary School (SLB) in Central Java. Therefore, it could see the amount of Human Resources certainty teacher that are both of honorer, state and private. So it calculated in the budget adjustment that will done by the Central Java Provincial Education Office in the payment of benefits for Extraordinary School (SLB) teachers to be paid.

All of the above recommendations need optimized in order to be equal to the state or private Extraordinary School (SLB) education in Central Java Province could realized later on.

\section{References}

1. Amran. (2009). Manajemen Personalia dan Sumber Daya Manusia. Jurnal Ichsan. https://doi.org/doi:10.1056/NEJMp1302259

2. Anderson, J. E. (1990). Public Policy Making: An Introduction. Psychiatric services Washington DC. https://doi.org/10.1176/appi.ps.61.11.1069

3. Anderson, J. E. (2003). Public Policymaking. Boston New York: Houghton Miffin Company.

4. Anggraeni, R., Zauhar, S., \& Siswidiyanto. (2011). Evaluasi Kebijakan Publik. Evaluasi Kebijakan Publik (Evaluasi Terhadap Proses Pengadaan Anjungan Mandiri Kepegawaian Berdasarkan Perpres No. 504 Tahun 2010 Kepegawaian Daerah Kota Malang).

5. Bohara, A. K., Mitchell, N. J., \& Mittendorff, C. F. (2004). Compound democracy and the control of corruption: A cross-country investigation. Policy Studies Journal. https://doi.org/10.1111/j.15410072.2004.00077.x

6. Dunn, W. N. (2003). Pengantar Analisis Kebijakan Publik edisi kedua. Yogyakarta: Gajah Mada University Press.

7. Dye, T. R. (2016). Understanding Public Policy. Understanding Public Policy.

8. Eulau, H., \& Easton, D. (2006). The Political System: An Inquiry into the State of Political Science. The Yale Law Journal. https://doi.org/10.2307/793409 
9. Hidayat, S. (2017). An Islamic Party in Urban Local Politics: The PKS Candidacy at the 2012 Jakarta Gubernatorial Election. Jurnal Politik. https://doi.org/10.7454/jp.v2i1.80

10. Jansi, K. R., Kasmir Raja, S. V., \& Sandhia, G. K. (2018). Efficient privacy-preserving fault tolerance aggregation for people-centric sensing system. In Service Oriented Computing and Applications. https://doi.org/10.1007/s11761-018-0241-5

11. Joko, W. (2016). PERATURAN PEMERINTAH REPUBLIK INDONESIA NOMOR 18 TAHUN 2016 TENTANG PERANGKAT DAERAH. In PERATURAN PEMERINTAH REPUBLIK INDONESIA NOMOR 18 TAHUN 2016 TENTANG PERANGKAT DAERAH.

12. Kaplan, G. A., \& Lynch, J. W. (2001). Is economic policy health policy? American Journal of Public Health. https://doi.org/10.2105/AJPH.91.3.351

13. Kasmir, S. (2009). Toward an anthropology of labor. City and Society. https://doi.org/10.1111/j.1548744X.2009.01011.x

14. Kawer, O. F. S., Baiquni, M., Keban, Y. T., \& Subarsono, A. (2018). IMPLEMENTASI KEBIJAKAN PEMBANGUNAN RUMAH LAYAK HUNI DENGAN PENDEKATAN HIBRIDA DI KABUPATEN SUPIORI PROVINSI PAPUA. Sosiohumaniora.

https://doi.org/10.24198/sosiohumaniora.v20i3.1848 9

15. Kemendikbud. (2013). Standar Isi Pendidikan Dasar dan Menengah. In Peraturan Menteri Pendidikan dan Kebedayaan.

16. Kementerian Pendidikan Nasional. (2010). Peraturan Pemerintah Republik Indonesia Nomor 66 Tahun 2010 tentang Perubahan atas Peraturan Pemerintah Republik Indonesia Nomor 17 Tahun 2010 tentang Pengelolaan dan Penyelenggaraan Pendidikan. uk.staff.ugm.ac.id.

17. Lasswell, H. D., \& Kaplan, A. (2018). Influence. In Power And Society. https://doi.org/10.4324/9781315127156-6

18. Lusli, M., Zweekhorst, M. B. M., Miranda-Galarza, B., Peters, R. M. H., Cummings, S., Seda, F. S. S. E., ... Irwanto. (2015). Dealing with stigma: Experiences of persons affected by disabilities and leprosy. BioMed Research International. https://doi.org/10.1155/2015/261329

19. Meyer, S. M., \& Dunn, W. N. (2006). Public Policy Analysis. Journal of Policy Analysis and Management. https://doi.org/10.2307/3324749
20. Notoatmojo, S. (2010). Pengembangan Sumber daya manusia. Jurnal LPPM Bidang EkoSosBudKum.

21. Novianto, A., Kurniawan, L., \& Wibawa, S. (2017). Krisis Kapitalisme 2008 dan Bangkitnya Gerakan Kiri Studi Dinamika Gerakan Partai Syriza di Yunani. Jurnal Ilmu Sosial Dan Ilmu Politik. https://doi.org/10.22146/jsp.15678

22. Nugroho, R. (2017). Public Policy: Dinamika Kebijakan, Analisis Kebijakan, dan Manajemen Politik Kebijakan Publik. Jakarta: Elex Media Komputindo. https://doi.org/10.1017/S0033291702006190

23. Pemerintah Republik Indonesia. (2014). UndangUndang Republik Indonesia Nomor 23 tahun 2014 tentang Pemerintahan Daerah. Kementerian Sekretariat Negara RI. https://doi.org/10.1017/CBO9781107415324.004

24. Profwork.org. (2014). The Public Policy Cycle. Easton Model.

25. Said, A. R., Abdullah, H., Uli, J., \& Mohamed, Z. A. (2014). Relationship between Organizational Characteristics and Information Security Knowledge Management Implementation. Procedia - Social and Behavioral Sciences. https://doi.org/10.1016/j.sbspro.2014.01.1442

26. Sedarmayanti. (2011). Manajemen Sumber Daya Manusia Reformasi Birokrasi dan Manajemen Pegawai Negeri Sipil. In Manajemen Sumber Daya Manusia.

27. Sugandi, Y. S. (2017). Sustainable Administrative Reform Movements Policy in Joko Widodo's Administration. Jurnal Ilmu Sosial Dan Ilmu Politik. https://doi.org/10.22146/jsp.24784

28. Van Rensburg, H., Basson, J. S., \& Carrim, N. M. H. (2011). Human resource management as a profession in South Africa. SA Journal of Human Resource Management. https://doi.org/10.4102/sajhrm.v9i1.336. 